\title{
Macrocarpal A, a Novel Antibacterial Compound from Eucalyptus macrocarpa
}

\author{
Masatsune Murata, Youko Yamakoshi, Seiichi Homma, \\ Koh Aida,** Kayako Hori* and Yuji OHASH* \\ Department of Nutrition and Food Science, and ${ }^{*}$ Department of Chemistry, \\ Ochanomizu University, 2-1-1, Otsuka, Bunkyo-ku, Tokyo 112, Japan \\ **Department of Food Science, Otsuma Women's University, \\ 12, 3-Bancho, Chiyoda-ku, Tokyo 102, Japan \\ Received June 15, 1990
}

\begin{abstract}
A novel antibacterial compound, macrocarpal A, was isolated from the leaves of Eucalyptus macrocarpa, and its structure was determined on the basis of an $\mathrm{X}$-ray crystal structure analysis. Macrocarpal A is composed of a phloroglucinol dialdehyde and diterpene, having a 3-membered ring, a 5-membered ring and a 7-membered ring.
\end{abstract}

Plants of the Eucalyptus species are widely distributed throughout the world and famous for their rapid growth. Recently, several biologically active compounds have been isolated from Eucalyptus species as biological resources. Grandinol ${ }^{1)}$ is a rooting inhibitor and was isolated from adult tissue of $E$. grandis. We have also isolated and identified grandinol as an antibacterial compound from $E$. perriniana. $^{2)}$ Euglobals ${ }^{3-5)}$ have been isolated from the buds and leaves of E. globulus and were found to show anti-inflammatory activity. Robustadials $^{6)}$ are antimalarial compounds and were isolated from E. robusta.

We are interested in antimicrobial compounds from plants of the Eucalyptus species,

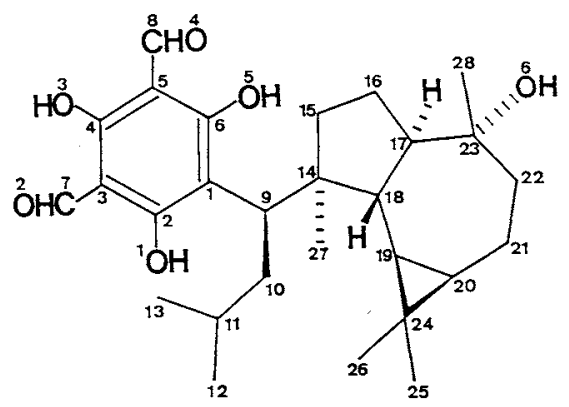

Fig. 1. Structure of Macrocarpal A. and have reported antibacterial compounds from E.perriniana. ${ }^{2)}$ In this paper, we described the isolation and structural elucidation of a novel antibacterial compound from $E$. macrocarpa. It was named macrocarpal A (1, Fig. 1) after the species name of the plant.

\section{Results and Discussion}

\section{Isolation and characterization}

An acetone extract of the leaves of the plant was fractionated into strongly acidic, weakly acidic, alkaline and neutral fractions in the usual way. The neutral fraction was further purified by silica gel column chromatography $\left(\mathrm{CHCl}_{3} / \mathrm{MeOH}\right)$, Sephadex LH-20. column chromatography, silica gel column chromatography $\left(\mathrm{CHCl}_{3} / \mathrm{AcOH}\right)$ and reversed-phase HPLC. Bacillus subtilis was used as a test organism in each step. As a result, several active compounds, which had similar physicochemical properties and antibacterial spectra, were isolated. ${ }^{7)}$ Compound $\mathbf{1}$ was crystallized from $\mathrm{MeOH}$.

Macrocarpal A (1), a colorless flat plate, $\mathrm{mp}$ $198-200^{\circ} \mathrm{C},[\alpha]_{\mathrm{D}}^{20}-94.7^{\circ}(c=0.275$, EtOH $)$, has molecular weight of 472 by negative FAB-MS $\left(m / z 471(\mathrm{M}-1)^{-}\right)$and the composi- 
tion $\mathrm{C}_{28} \mathrm{H}_{40} \mathrm{O}_{6}$, which were finally determined by the results of an X-ray crystal structure analysis. The UV spectrum of $1\left(\lambda_{\max }(\mathrm{EtOH})\right.$ $\mathrm{nm}(\varepsilon)$ : $275(13,000), 393(5600))$ is in good agreement with the data reported for grandinol and euglobals. Fragmentation peaks of EI-MS at $m / z$ 454, 397, 251, 204, 203, 195 and 161 were similar to euglobals III, IV, V and VII. These data suggest that $\mathbf{1}$ has a similarly substituted phloroglucinol chromophore. The $270 \mathrm{MHz}{ }^{1} \mathrm{H}$-NMR spectrum of 1 showed two hydrogen-bonded phenolic hydroxyls $(\delta 13.57)$, a phenolic hydroxyl $(\delta 6.00)$, two aldehyde groups $(\delta 10.13,10.19)$, two methine protons $(\delta$ $0.54,0.65)$ on a cyclopropane ring, a methine proton $(\delta 3.67)$ adjacent to the phloroglucinol and isobutyl side chain, four singlet methyls ( $\delta$ $0.75-1.15)$ and two doublet methyls $(\delta 0.83$, $0.80)$. The ${ }^{13} \mathrm{C}-\mathrm{NMR}$ spectrum of 1 showed six methyl carbons, five methylene carbons, six methine carbons, two quaternary carbons and a quaternary carbon bearing a oxygen atom in the region of the $\mathrm{sp}^{3}$ carbons.

These results show that 1 has a similar structure to euglobals III, IV, V and VII, which are composed of a phloroglucinol part and a diterpene part, but that $\mathbf{1}$ is different from euglobals III, IV, V and VII.

\section{Structure}

The structure of 1 was determined by an $\mathrm{X}$-ray crystal structure analysis. The crystal data are as follows: $\mathrm{C}_{28} \mathrm{H}_{40} \mathrm{O}_{6}, \mathrm{MW} \mathrm{472.62,}$ monoclinic, space group $\mathrm{P} 2_{1}, a=8.578$ (3), $b=21.800(7), c=7.233$ (2) $\AA, \beta=103.34(2)^{\circ}$, $V=1316.0(7) \AA^{3}, Z=2, D_{X}=1.19 \mathrm{~g} \cdot \mathrm{cm}^{-3}$. The final $R$ value was 0.060 for 3133 reflections. The final atomic parameters for the nonhydrogen atoms are given in Table $\mathrm{I}^{8}{ }^{8}$ The molecular structure of $\mathbf{1}$ with the numbering of the atoms is shown in Fig. 2. Macrocarpal A has seven asymmetric carbon atoms, whose relative configurations were determined. The bond distances and angles are listed in Table II, and the torsion angles in Table 3. The three-membered ring condensed with a sevenmembered ring is an approximately equiangular triangle $\left(59.8,60.1\right.$ and $\left.60.1^{\circ}\right)$. The seven-
Table I. Final Atomic CoOrdinates $\left(\times 10^{4}\right)$ AND Equivalent Isotropic Temperature Factors FOR NON-HYDROGEN ATOMS OF Macrocalpal A

\begin{tabular}{|c|c|c|c|c|}
\hline Atom & $x$ & $y$ & $z$ & $B(\mathrm{eq})$ \\
\hline$O(1)$ & $1867(3)$ & $8262(1)$ & $1349(3)$ & 4.1 \\
\hline$O(2)$ & $-94(3)$ & $7407(1)$ & $-232(4)$ & 5.0 \\
\hline$O(3)$ & $676(4)$ & $6542(1)$ & $4724(4)$ & 5.1 \\
\hline$O(4)$ & $3653(4)$ & $7151(1)$ & $9664(4)$ & 5.4 \\
\hline$O(5)$ & $3991(3)$ & 8157 & 7937 (4) & 4.5 \\
\hline$O(6)$ & $923(4)$ & $11440(\mathrm{I})$ & $2704(4)$ & 4.6 \\
\hline$C(1)$ & $2946(3)$ & 8250 (I) & $4653(4)$ & 2.9 \\
\hline$C(2)$ & 2024 (3) & 7974 (1) & $3032(4)$ & 3.1 \\
\hline C ( 3$)$ & $1222(3)$ & 7405 (1) & 3052 (4) & 3.4 \\
\hline$C(4)$ & $1410(4)$ & 7087 (1) & $4752(5)$ & 3.5 \\
\hline$C(5)$ & 2384 & 7327 (1) & $6424(4)$ & 3.5 \\
\hline$C(6)$ & $3101(3)$ & $7916(1)$ & $6335(4)$ & 3.2 \\
\hline$C(7)$ & $190(4)$ & $7161(2)$ & $1346(6)$ & 4.5 \\
\hline C ( 8) & $2784(4)$ & $6971(2)$ & $8156(6)$ & 4.4 \\
\hline$C(9)$ & 3777 (3) & 8874 (I) & 4681 (4) & 2.8 \\
\hline$C(10)$ & $4883(4)$ & $8890(1)$ & $3282(5)$ & 3.4 \\
\hline$C(11)$ & $6084(4)$ & $8351(1)$ & $3481(6)$ & 4.4 \\
\hline$C(12)$ & $7085(5)$ & $8415(3)$ & $1970(7)$ & 6.3 \\
\hline$C(13)$ & $7172(5)$ & $8294(2)$ & $5473(7)$ & 5.8 \\
\hline C (14) & $2566(3)$ & $9422(1)$ & $4534(4)$ & 3.0 \\
\hline$C(15)$ & $1441(4)$ & $9522(2)$ & $2589(5)$ & 4.3 \\
\hline$C(16)$ & $740(4)$ & $10166(2)$ & $2691(6)$ & 4.7 \\
\hline$C(17)$ & $2014(3)$ & $10526(1)$ & $4133(4)$ & 2.9 \\
\hline C (18) & $3415(3)$ & $10063(1)$ & $4843(4)$ & 2.5 \\
\hline C (19) & $4309(3)$ & $10209(1)$ & $6853(4)$ & 3.2 \\
\hline$C(20)$ & $5102(4)$ & $10826(2)$ & $7343(5)$ & 4.0 \\
\hline$C(21)$ & $5158(4)$ & $11292(2)$ & $5845(6)$ & 4.4 \\
\hline$C(22)$ & $3530(5)$ & $11545(1)$ & $4861(6)$ & 4.5 \\
\hline$C(23)$ & $2498(4)$ & $11138(1)$ & 3359 (4) & 3.6 \\
\hline C (24) & $6112(4)$ & $10248(2)$ & $7589(6)$ & 5.2 \\
\hline$C(25)$ & $7259(4)$ & $10140(2)$ & $6343(9)$ & 7.1 \\
\hline $\mathrm{C}(26)$ & $6708(8)$ & $10042(4)$ & $9655(9)$ & 10.1 \\
\hline C (27) & $1572(4)$ & $9319(2)$ & $6029(6)$ & 4.6 \\
\hline C (28) & $3207(5)$ & $11071(2)$ & $1610(5)$ & 5.3 \\
\hline
\end{tabular}

membered ring is bent at the $\mathrm{C}(18) \cdots \mathrm{C}(21)$ and $\mathrm{C}(17) \cdots \mathrm{C}(22)$ axes, and the atoms of $\mathrm{C}(18)-\mathrm{C}(19)-\mathrm{C}(20)-\mathrm{C}(21)$ and $\mathrm{C}(17)-\mathrm{C}(18) \cdots$ $\mathrm{C}(21) \mathrm{C}(22)$ lie fairly well on a plane, respectively. It resembles a chair form. The fivemembered ring is bent at the $\mathrm{C}(15) \cdots \mathrm{C}(18)$ axis, and the atoms of $\mathrm{C}(15) \mathrm{C}(16) \mathrm{C}(17)$ $\mathrm{C}(18)$ are planar. The bond distances of $\mathrm{C}(14)-\mathrm{C}(18)(1.567 \AA), \mathrm{C}(17)-\mathrm{C}(18)(1.563 \AA)$ and $\mathrm{C}(9)-\mathrm{C}(14)(1.571 \AA)$ are significantly longer than the other bonds, which are considered to be caused by steric repulsion between the bulky substituents. The aromatic 
Table II. Bond Distances ( $\AA$ ) And Angles (deg) for Macrocarpal A

\begin{tabular}{cc}
\hline Bond & Distance \\
\hline $\mathrm{O}(1)-\mathrm{C}(2)$ & $1.349(4)$ \\
$\mathrm{O}(2)-\mathrm{C}(7)$ & $1.233(5)$ \\
$\mathrm{O}(3)-\mathrm{C}(4)$ & $1.342(5)$ \\
$\mathrm{O}(4)-\mathrm{C}(8)$ & $1.235(5)$ \\
$\mathrm{O}(6) \mathrm{C}(23)$ & $1.479(4)$ \\
$\mathrm{C}(1)-\mathrm{C}(2)$ & $1.391(4)$ \\
$\mathrm{C}(1) \mathrm{C}(6)$ & $1.398(4)$ \\
$\mathrm{C}(1)-\mathrm{C}(9)$ & $1.533(4)$ \\
$\mathrm{C}(2)-\mathrm{C}(3)$ & $1.420(4)$ \\
$\mathrm{C}(3) \mathrm{C}(4)$ & $1.388(5)$ \\
$\mathrm{C}(3)-\mathrm{C}(7)$ & $1.444(5)$ \\
$\mathrm{C}(4)-\mathrm{C}(5)$ & $1.403(5)$ \\
$\mathrm{C}(5)-\mathrm{C}(6)$ & $1.432(4)$ \\
$\mathrm{C}(5)-\mathrm{C}(8)$ & $1.445(5)$ \\
$\mathrm{C}(9)-\mathrm{C}(10)$ & $1.539(5)$ \\
$\mathrm{C}(9)-\mathrm{C}(14)$ & $1.571(4)$ \\
$\mathrm{C}(10)-\mathrm{C}(11)$ & $1.547(6)$ \\
$\mathrm{C}(11)-\mathrm{C}(12)$ & $1.544(7)$ \\
$\mathrm{C}(11)-\mathrm{C}(13)$ & $1.530(7)$ \\
$\mathrm{C}(14)-\mathrm{C}(15)$ & $1.527(5)$ \\
$\mathrm{C}(14)-\mathrm{C}(18)$ & $1.567(4)$ \\
$\mathrm{C}(14)-\mathrm{C}(27)$ & $1.540(5)$ \\
$\mathrm{C}(15)-\mathrm{C}(16)$ & $1.535(6)$ \\
$\mathrm{C}(16)-\mathrm{C}(17)$ & $1.540(5)$ \\
$\mathrm{C}(17)-\mathrm{C}(18)$ & $1.563(4)$ \\
$\mathrm{C}(17)-\mathrm{C}(23)$ & $1.541(4)$ \\
$\mathrm{C}(18)-\mathrm{C}(19)$ & $1.513(4)$ \\
$\mathrm{C}(19)-\mathrm{C}(20)$ & $1.513(4)$ \\
$\mathrm{C}(19)-\mathrm{C}(24)$ & $1.517(5)$ \\
$\mathrm{C}(20)-\mathrm{C}(21)$ & $1.494(6)$ \\
$\mathrm{C}(20)-\mathrm{C}(24)$ & $1.517(6)$ \\
$\mathrm{C}(21)-\mathrm{C}(22)$ & $1.517(6)$ \\
$\mathrm{C}(22)-\mathrm{C}(23)$ & $1.519(5)$ \\
$\mathrm{C}(23)-\mathrm{C}(28)$ & $1.532(6)$ \\
$\mathrm{C}(24)-\mathrm{C}(25)$ & $1.498(8)$ \\
$\mathrm{C}(24)-\mathrm{C}(26)$ & \\
\hline & \\
\hline & \\
\hline &
\end{tabular}

\begin{tabular}{|c|c|}
\hline Bond & Angle \\
\hline$C(2)-C(1)-C(6)$ & $115.4(3)$ \\
\hline$C(2)-C(1)-C(9)$ & $124.5(2)$ \\
\hline$C(6)-C(1)-C(9)$ & $120.0(2)$ \\
\hline $\mathrm{O}(1)-\mathrm{C}(2)-\mathrm{C}(1)$ & $118.6(3)$ \\
\hline $\mathrm{O}(1)-\mathrm{C}(2)-\mathrm{C}(3)$ & $117.9(3)$ \\
\hline$C(1)-C(2)-C(3)$ & $123.5(3)$ \\
\hline $\mathrm{C}(2)-\mathrm{C}(3)-\mathrm{C}(4)$ & $119.2(3)$ \\
\hline $\mathrm{C}(2)-\mathrm{C}(3)-\mathrm{C}(7)$ & $121.1(3)$ \\
\hline$C(4)-C(3)-C(7)$ & $119.8(3)$ \\
\hline $\mathrm{O}(3)-\mathrm{C}(4)-\mathrm{C}(3)$ & $118.1(3)$ \\
\hline $\mathrm{O}(3) \mathrm{C}(4)-\mathrm{C}(5)$ & $121.7(3)$ \\
\hline$C(3)-C(4)-C(5)$ & $120.2(3)$ \\
\hline$C(4)-C(5)-C(6)$ & $118.1(3)$ \\
\hline$C(4) C(5)-C(8)$ & $121.5(3)$ \\
\hline$C(6)-C(5)-C(8)$ & $120.1(3)$ \\
\hline$C(1) C(6)-C(5)$ & $123.5(3)$ \\
\hline $\mathrm{O}(2)-\mathrm{C}(7)-\mathrm{C}(3)$ & $125.6(4)$ \\
\hline $\mathrm{O}(4)-\mathrm{C}(8)-\mathrm{C}(5)$ & $124.7(4)$ \\
\hline$C(1) C(9) C(10)$ & $111.5(2)$ \\
\hline$C(1)-C(9)-C(14)$ & $112.1(2)$ \\
\hline$C(10) C(9)-C(14)$ & $115.9(2)$ \\
\hline$C(9)-C(10)-C(11)$ & $114.8(3)$ \\
\hline$C(10)-C(11)-C(12)$ & $109.4(4)$ \\
\hline$C(10) C(11)-C(13)$ & $113.5(3)$ \\
\hline $\mathrm{C}(12)-\mathrm{C}(11)-\mathrm{C}(13)$ & $110.8(4)$ \\
\hline$C(9) C(14)-C(15)$ & $116.0(3)$ \\
\hline$C(9)-C(14)-C(18)$ & $113.0(2)$ \\
\hline $\mathrm{C}(9)-\mathrm{C}(14)-\mathrm{C}(27)$ & $107.8(3)$ \\
\hline$C(15)-C(14)-C(18)$ & $100.3(2)$ \\
\hline$C(15)-C(14)-C(27)$ & $109.5(3)$ \\
\hline $\mathrm{C}(18) \mathrm{C}(14)-\mathrm{C}(27)$ & $110.2(3)$ \\
\hline$C(14)-C(15)-C(16)$ & $104.9(3)$ \\
\hline$C(15) C(16) C(17)$ & $105.9(3)$ \\
\hline$C(16)-C(17)-C(18)$ & $105.4(2)$ \\
\hline$C(16)-C(17)-C(23)$ & $113.9(3)$ \\
\hline $\mathrm{C}(18)-\mathrm{C}(17)-\mathrm{C}(23)$ & $115.3(2)$ \\
\hline $\mathrm{C}(14)-\mathrm{C}(18)-\mathrm{C}(17)$ & $103.4(2)$ \\
\hline$C(14)-C(18)-C(19)$ & $116.1(2)$ \\
\hline $\mathrm{C}(17)-\mathrm{C}(18)-\mathrm{C}(19)$ & $111.2(2)$ \\
\hline $\mathrm{C}(18)-\mathrm{C}(19)-\mathrm{C}(20)$ & $120.8(2)$ \\
\hline $\mathrm{C}(18)-\mathrm{C}(19)-\mathrm{C}(24)$ & $126.8(3)$ \\
\hline $\mathrm{C}(20)-\mathrm{C}(19)-\mathrm{C}(24)$ & $60.1(2)$ \\
\hline$C(19)-C(20)-C(21)$ & $121.5(3)$ \\
\hline$C(19)-C(20)-C(24)$ & $60.1(2)$ \\
\hline$C(21)-C(20)-C(24)$ & $122.5(3)$ \\
\hline$C(20)-C(21)-C(22)$ & $114.1(3)$ \\
\hline$C(2 \mathrm{I})-\mathrm{C}(22)-\mathrm{C}(23)$ & $116.4(3)$ \\
\hline $\mathrm{O}(6)-\mathrm{C}(23)-\mathrm{C}(17)$ & $101.5(2)$ \\
\hline $\mathrm{O}(6)-\mathrm{C}(23)-\mathrm{C}(22)$ & $107.9(3)$ \\
\hline $\mathrm{O}(6)-\mathrm{C}(23)-\mathrm{C}(28)$ & $106.6(3)$ \\
\hline$C(17)-C(23)-C(22)$ & $114.1(3)$ \\
\hline $\mathrm{C}(17)-\mathrm{C}(23)-\mathrm{C}(28)$ & $114.1(3)$ \\
\hline$C(22)-C(23)-C(28)$ & $111.6(3)$ \\
\hline $\mathrm{C}(19)-\mathrm{C}(24)-\mathrm{C}(20)$ & $59.8(2)$ \\
\hline$C(19)-C(24)-C(25)$ & $122.5(4)$ \\
\hline$C(19)-C(24)-C(26)$ & $114.2(4)$ \\
\hline$C(20)-C(24)-C(25)$ & $119.8(4)$ \\
\hline$C(20)-C(24)-C(26)$ & $114.3(4)$ \\
\hline$C(25)-C(24)-C(26)$ & $115.1(5)$ \\
\hline
\end{tabular}




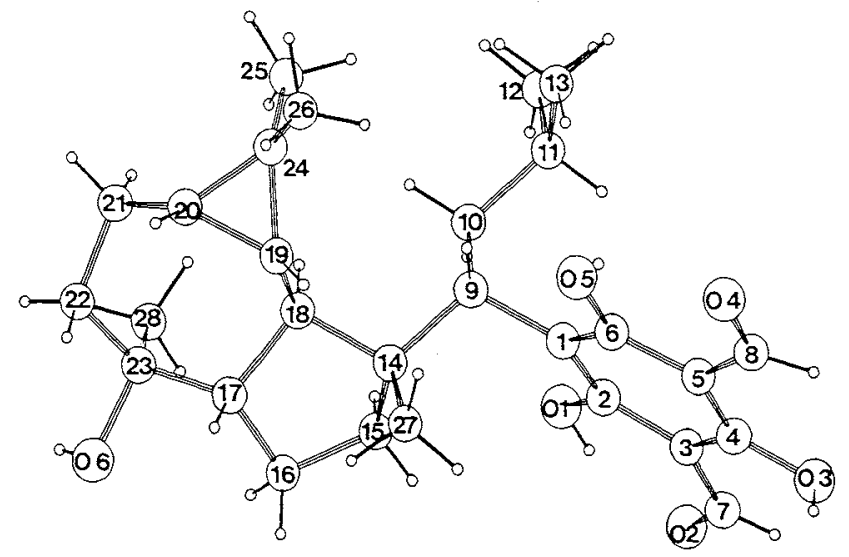

Fig. 2. Perspective View of Macrocalpal A.

The absolute configuration is tentative.

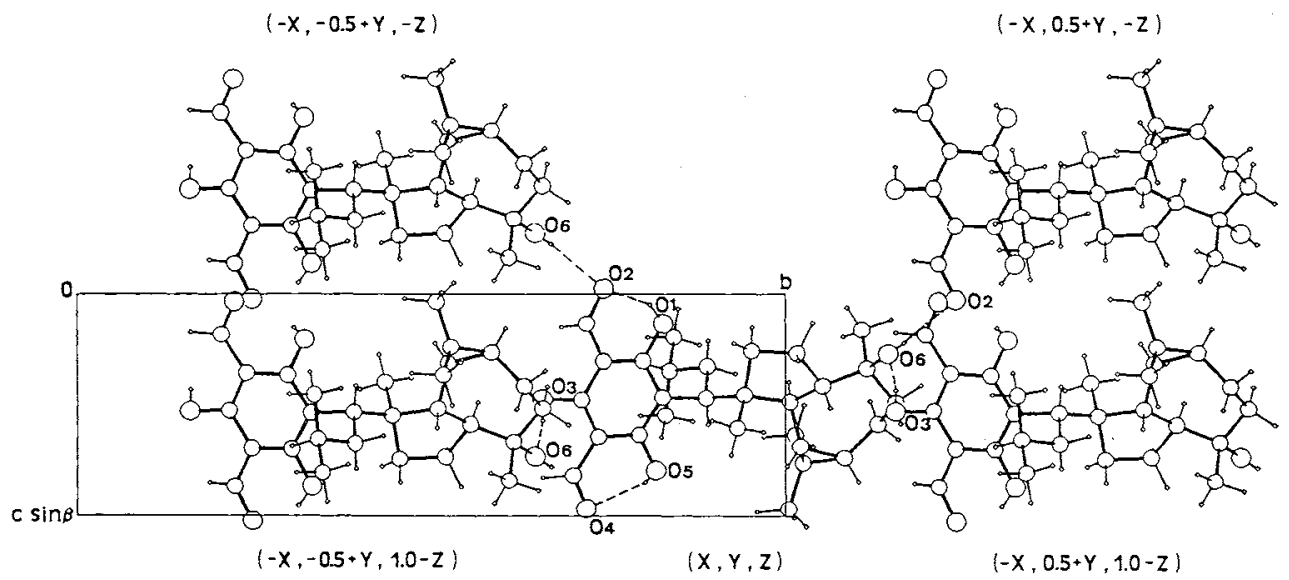

Fig. 3. Crystal Structure of Macrocarpal A.

The a axis is down from the plane of the paper. ---, hydrogen bonds: $0(1)-\cdots-0(2), 2.593 \AA ; 0(4)---0(5)$, $2.571 \AA ; 0(6)--0(2), 2.748 \AA ; 0(6)-0(3), 2.563 \AA$.

Table III. TORSION ANGles (deg) FOR MACROCARPAL A

\begin{tabular}{lc}
\hline$C(A)-C(B)-C(C)-C(D)$ & Torsion angle \\
\hline$C(14)-C(15)-C(16)-C(17)$ & 28.0 \\
$C(15)-C(16)-C(17)-C(18)$ & -0.9 \\
$C(16)-C(17)-C(18)-C(14)$ & -25.6 \\
$C(17)-C(18)-C(14)-C(15)$ & 42.1 \\
$C(18)-C(14)-C(15)-C(16)$ & -43.2 \\
$C(23)-C(17)-C(18)-C(19)$ & 82.7 \\
$C(17)-C(18)-C(19)-C(20)$ & -58.9 \\
$C(18)-C(19)-C(20)-C(21)$ & -5.5 \\
$C(19)-C(20)-C(21)-C(22)$ & 66.2 \\
$C(20)-C(21)-C(22)-C(23)$ & -77.9 \\
$C(21)-C(22)-C(23)-C(17)$ & 62.9 \\
$C(22)-C(23)-C(17)-C(18)$ & -67.9 \\
$C(17)-C(18)-C(21)-C(22)$ & -3.8 \\
\hline
\end{tabular}

ring is planar within experimental error. Hydroxyl groups $\mathrm{O}(1)$ and $\mathrm{O}(5)$ are hydrogenbonded to oxygen atoms $O(2)$ and $O(4)$ of the aldehyde groups, respectively. The bond distance of $\mathrm{C}(23)-\mathrm{O}(6)(1.479 \AA)$ is significantly longer than the other $\mathrm{C}-\mathrm{O}$ bonds. The crystal structure is shown in Fig. 3. A unit cell contains two molecules of macrocarpal A. Hydroxyl group $\mathrm{O}(6)$ is hydrogen-bonded to $\mathrm{O}(2)$ of the carbonyl group of a neighboring molecule $(\mathrm{O}(6)(\mathrm{X}, \mathrm{Y}, \mathrm{Z}) \cdots \mathrm{O}(2)(-\mathrm{X}, 0.5+\mathrm{Y},-\mathrm{Z})$, $2.748 \AA$ ) and $\mathrm{O}(3)$ of the hydroxyl group of another neighboring molecule $(\mathrm{O}(6)(\mathrm{X}, \mathrm{Y}$, Z) $\cdots \mathrm{O}(3)(-\mathrm{X}, 0.5+\mathrm{Y}, 1.0-\mathrm{Z}), 2.563 \AA)$. There are no unusually short contacts between 

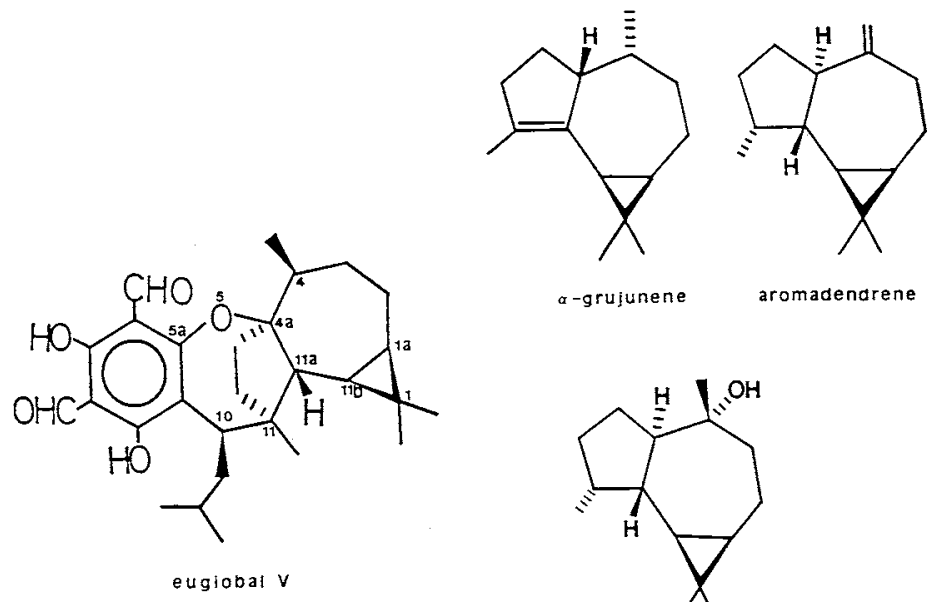

a-grujunene

aromadendrene

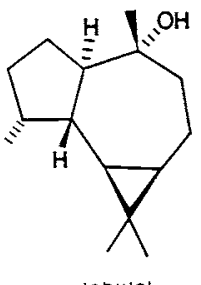

globulal

Fig. 4. Structures of Related Compounds.

the molecules in the crystals, except for these hydrogen bonds.

Compound $\mathbf{1}$ is a novel compound which has a phloroglucinol dialdehyde and diterpene structure. A structurally related compound, euglobal V (Fig. 4), has a phloroglucinol dialdehyde and diterpene. Euglobal $\mathrm{V}$ has an ether bond, $\mathrm{C}(5 \mathrm{a}) \mathrm{O}(5) \mathrm{C}(4 \mathrm{a})$, between the aromatic moiety and non-aromatic moiety. On the other hand, macrocarpal $\mathrm{A}$ has no ether bond between $\mathrm{C}(2), \mathrm{O}(1)$ and $\mathrm{C}(17)$, which correspond to $\mathrm{C}(5 \mathrm{a}), \mathrm{O}(5)$ and $\mathrm{C}(4 \mathrm{a})$ in euglobal $\mathrm{V}$, respectively. Moreover, macrocarpal $\mathrm{A}$ has a hydroxyl group in the non-aromatic part, which is bound to $\mathrm{C}(23)$. The part involving a 3 -membered ring, 5 -membered ring and 7-membered ring is the same as that in the structure of globulo1. ${ }^{9)}$ Euglobal $\mathrm{V}^{5)}$ is considered to be biogenetically derived from an isovaleroylphloroglucinol dialdehyde precursor and bicyclogermacrene, which is the common precursor of aromadendrene derivatives isolated from E. globlus such as $\alpha$-grujunene, aromadendrene and globulol (Fig. 4). The relationship between these two compounds in biosynthesis is interesting.

\section{Antimicrobial activity}

Macrocarpal A showed antibacterial activity against Gram-positive bacteria such as Bacillus subtilis PCI219 and Staphylococcus aureus FDA209P (minimum inhibitory concentration $<0.2 \mu \mathrm{g} / \mathrm{ml}$ and $0.4 \mu \mathrm{g} / \mathrm{ml}$, respectively) but no activity against Gram-negative bacteria such as Escherichia coli NIHJ and Pseudomonas aeruginosa P-3, yeast and fungi such as Saccharomyces cerevisiae and Aspergillus niger.

\section{Experimental}

General. The melting point ( $\mathrm{mp}$ ) was determined by a Yanagimoto micro-melting point measurement instrument. Spectroscopic measurements were carried out by using the following instruments: Hitachi 200-20 (UV), JAS IRA-I (IR), JEOL JMS-DX300 and JEOL JMA-DA 5000 (EI-MS), JEOL JMS-SX 102 (FAB-MS), JAS DIP-181 $\left([\alpha]_{\mathrm{D}}\right)$ and JEOL JNM-GX270 (NMR).

Isolation of macrocarpal $A(\mathbf{1}){ }^{7)}$ The leaves of $E$. macrocarpa $(2880 \mathrm{~g})$ were freeze-dried and then extracted with $80 \%$ acetone. The acetone extract was fractionated into the strongly acidic, weakly acidic, alkaline and neutral fractions by EtOAc in the usual way. The neutral fraction was applied to a silica gel column, which was developed with $\mathrm{CHCl}_{3}-\mathrm{MeOH}(10: 1 \rightarrow 2: 1)$. The active fractions which were eluted with $\mathrm{CHCl}_{3}-\mathrm{MeOH}(2: 1)$ were collected and concentrated in vacuo, and then applied to a column of Sephadex LH-20. The column was developed with $\mathrm{MeOH}$, and four active fractions were separated. The first fraction was concentrated in vacuo and applied to a column of silica gel, which was developed with $\mathrm{CHCl}_{3}-\mathrm{AcOH}$ $(200: 1 \rightarrow 50: 1)$. The active fraction was collected and 
concentrated in vacuo, compound $\mathbf{1}$ being crystallized in this concentrate and recrystallized from $\mathrm{MeOH}$.

Physico-chemical properties of 1 . Colorless flat plate; $\mathrm{mp}$ $198-200^{\circ} \mathrm{C} ;[\alpha]_{\mathrm{D}}^{20}-94.7^{\circ}(c=0.275$, EtOH). Anal. Found: C, $70.76 \% ; \mathrm{H}, 8.58 \%$. Calcd. for $\mathrm{C}_{28} \mathrm{H}_{40} \mathrm{O}_{6}$ : C, 71.17\%; $\mathrm{H}, 8.53 \%$. UV $\lambda_{\text {max }}(\mathrm{EtOH}) \mathrm{nm}(\varepsilon): 275(13,000), 393(5600)$; $\lambda_{\max }\left(0.01 \mathrm{~N} \mathrm{HCl}\right.$ in EtOH) $\mathrm{nm}(\varepsilon): 288(10,000) ; \lambda_{\max }(0.01 \mathrm{~N}$ $\mathrm{NaOH}$ in EtOH) nm $(\varepsilon): 302(16,000), 369$ (2500); IR $v$ $\mathrm{cm}^{-1}$ (KBr): 3390, 2940, 1610, 1440, 1375, 1317, 1180, 760; EI-MS (m/z): 454, 397, 251, 222, 204 (100), 203 (100), 195 (100), 161; negative FAB-MS: $m / z 471(\mathrm{M}-1)^{-}$; ${ }^{1} \mathrm{H}-\mathrm{NMR} \delta\left(\mathrm{CDCl}_{3}\right): 13.57(2 \mathrm{H}, \mathrm{s}), 10.19(1 \mathrm{H}, \mathrm{s}), 10.13$ $(1 \mathrm{H}, \mathrm{s}), 6.00(1 \mathrm{H}, \mathrm{br} . \mathrm{s}), 3.67(1 \mathrm{H}, \mathrm{m}), 2.05-1.14(14 \mathrm{H}), 1.15$ $(3 \mathrm{H}, \mathrm{s}), 1.11(3 \mathrm{H}, \mathrm{s}), 1.09(3 \mathrm{H}, \mathrm{s}), 0.83(3 \mathrm{H}, \mathrm{d}, J=5.9 \mathrm{~Hz})$, $0.80(3 \mathrm{H}, \mathrm{d}, J=5.6 \mathrm{~Hz}), 0.75(3 \mathrm{H}, \mathrm{s}), 0.65(1 \mathrm{H}, \mathrm{m}), 0.54$ $(1 \mathrm{H}, \quad \mathrm{t}, \quad J=9.8 \mathrm{~Hz}) ; \quad{ }^{13} \mathrm{C}-\mathrm{NMR} \quad \delta \quad\left(\mathrm{CDCl}_{3}\right): 192.20$ $(2 \times \mathrm{CHO}), 170.00(\mathrm{~s}), 167.89(\mathrm{~s}), 164.69$ (s), 106.89 (s), 104.29 (s), 103.69 (s), 75.69 (s), 53.85 (d), 48.15 (s), 44.42 (d), $44.42(\mathrm{t}), 35.24(\mathrm{t}), 34.94(\mathrm{t}), 34.14(\mathrm{~d}), 28.88(\mathrm{q}), 27.13$ (d), 27.03 (d), 25.77 (d), 24.35 (t), 24.35 (q), 22.07 (q), 20.83 (q), 20.35 (t), $20.35(\mathrm{q}), 19.80(\mathrm{~s}), 17.52(\mathrm{q})$.

Crystal-structure analysis of 1 . The preliminary unitcell dimensions and space group were determined from photographs; systematic absences were $k=2 n+1$ for $0 k 0$. A crystal of approximate size $0.65 \times 0.45 \times 0.30 \mathrm{~mm}$ was mounted on a rotating-anode Rigaku off-centered fourcircle diffractometer, Mo- $K_{\alpha}$ radiation monochromated by graphite being used. Unit-cell dimensions were obtained from $2 \theta$ values of 17 reflections in the range of $19<2 \theta<$ $30^{\circ}$. Intensities were measured up to $2 \theta=55^{\circ}$; ranges of $h, k, l$ were $-11-10,0-28$ and $0-9$, respectively. The $\omega / 2 \theta$ scan technique was applied, the scanning rate and width being $4^{\circ}(\theta) \mathrm{min}^{-1}$ and $(1.0+0.35 \tan \theta)^{\circ}$, respectively. Stationary background counts were accumulated for $5 \mathrm{~s}$ before and after each scan. Three standard reflections of $-2101,-562$ and -204 were measured for every 50 reflections, and no significant intensity change was observed. A total of 3263 independent reflections were measured, of which 3133 with $\left|F_{0}\right|>3 \sigma\left(\left|F_{0}\right|\right)$ were used for the structural determination. Lorentz and polarization, but no absorption and extinction, corrections were applied.

The structure was solved by the direct method, using the MULTAN 78 ${ }^{10}$ program, and were refined by fullmatrix least-squares with SHELX 76. ${ }^{11}$ The weighting scheme was $\omega=\left[\sigma\left(\left|F_{o}\right|\right)^{2}+0.004\left(\left|F_{O}\right|^{2}\right)\right]^{-1}$. Final refinement was performed with anisotropic thermal parameters for the carbon and oxygen atoms, and with isotropic ones for the hydrogen atoms. ${ }^{8)}$ The maximum values of $(A / \sigma)$ and $\Delta \rho$ were 0.1 and $0.2 \mathrm{e} \AA^{-3}$, respectively. Final $R$ and $R_{\mathrm{w}}$ values were 0.060 and 0.067 , respectively, for 3133 reflections. Computation was performed on an IBM 4381R24 in the computer center of Ochanomizu University, and graphics was carried out on an $\mathrm{M}-280 \mathrm{H}$ computer at the computer center of the University of Tokyo.

Assay for antimicrobial activity. The minimum inhibitory concentration was assayed by the agar dilution method. Nutrient agar was used for bacteria, and potato dextrose agar was used for yeast and fungi as test media. Bacteria were incubated at $37^{\circ} \mathrm{C}$ for $24 \mathrm{hr}$, and yeast and fungi were incubated at $27^{\circ} \mathrm{C}$ for $48 \mathrm{hr}$.

Acknowledgments. We wish to thank Dr. Norio Kondo, President of the Research Institute of Revolutionary Biology, Setagaya-ku, Tokyo, and Dr. Minoru Amano, Faculty of Agriculture, Tokyo University of Agriculture, Setagaya-ku, Tokyo, for supplying the sample of Eucalyptus macrocarpa, and Dr. Koshi Arai, Sapporo Breweries Ltd., Yaizu-shi, Shizuoka, for measuring FAB-MS.

\section{References}

1) W. D. Crow, T. Osawa, D. M. Paton and R. R. Willing, Tetrahedron Lett., 1977, 1073.

2) R. Nakayama, M. Murata, S. Homma and K. Aida, Agric. Biol. Chem., 54, 231 (1990).

3) T. Amano, T. Komiya, M. Hori and M. Goto, $J$. Chromatogr., 13, 545 (1981).

4) M. Kozuka, T. Sawada, F. Kasahara, E. Mizuta, T. Amino, T. Komiya and M. Goto, Chem. Pharm. Bull., 30, 1952 (1982).

5) M. Kozuka, T. Sawada, E. Mizuta, F. Kasahara, T. Amano, T. Komiya and M. Goto, Chem. Pharm. Bull., 30, 1964 (1982).

6) R. Xu, J. K. Snyder and K. Nakanishi, J. Am. Chem. Soc., 106, 734 (1984).

7) M. Murata, Y. Yamakoshi, S. Homma and K. Aida, in preparation.

8) List of the anisotropic thermal parameters, $H$ atom parameters, and an $F O-F C$ table are available from one of the authors (M. Murata) on request.

9) G. Burch, W. Hofheinz and J. V. Paukstelis, J. Am. Chem. Soc., 91, 647 (1969).

10) P. Main, L. Lessinger, M. M. Woolfson, G. Germain and J. P. Declercq, MULTAN 78, A System of Computer Programs for the Automatic Solution of Crystal Structure from X-Ray Diffraction Data: University of York, York, United Kingdom, and University of Louvain, Louvain, Belgium, 1978.

11) G. M. Scheldrick, SHELX 76, A Program for Crystal Structure Determination, University of Cambridge, United Kingdom, 1976. 